\title{
LA OSCURA MEMORIA: CINE NEGRO Y BRECHAS FANTÁSTICAS EN ENTERRAR A LOS MUERTOS (2005) Y LAS SERPIENTES CIEGAS (2008) [UNA CONTRAPOSICIÓN]
}

\author{
Álvaro López Fernández \\ alfernandez@ucm.es \\ Universidad Complutense de Madrid \\ Raúl Molina GIL \\ molinagilraul@gmail.com \\ Universidad de Valencia
}

Recibido: 15-12-2016

Aceptado: 14-05-2017

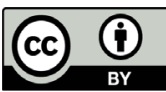

RESUMEN

La literatura en torno a la memoria es uno de los puntales de la narrativa hispánica reciente. Lo que este artículo pretende es adentrarse en una de sus áreas más inexploradas (las purgas estalinistas en España durante la Guerra Civil) a través del análisis y la confrontación de dos obras tan reconocidas como heterodoxas: la novela Enterrar a los muertos, de Ignacio Martínez de Pisón, y el cómic Las serpientes ciegas, de Felipe Hernández Cava y Bartolomé Seguí. La pasarela que comunica ambos textos es la estética de cine negro que ambienta el cómic y que — como intentaremos demostrarmodula la tensión de la novela. El final del camino lo marca el empleo de lo fantástico por parte de Cava y Seguí, cuya repercusión se estudiará con detalle en las páginas sucesivas. Y es que no son muchas las producciones que han logrado romper con el realismo dominante de esta literatura...

PAlabras Clave: noir, cómic, fantástico, Guerra Civil, memoria,

\section{ABSTRACT}

Memory literature is a pillar of recent Spanish prose fiction. This article takes aim at one of its more unexplored areas (Stalinist purges in Spain during the Civil War) 
through the analysis and comparison of two well-known and heterodox works: the novel Enterrar a los muertos, by Ignacio Martínez de Pisón, and the comic Las serpientes ciegas, by Felipe Hernández Cava and Bartolomé Seguí. The connection between both texts is the film noir aesthetic which permeates the comic and which —as we intend to show- structures the tension in the novel. The end of the journey is the use that Cava and Seguí make of the fantastic, whose consequences are studied in detail in the following pages. There are not many compositions which have managed to break away from the realism prevalent in this kind of literature.

KeY WORDs: noir, comic, fantastic, Civil War, memory.

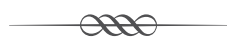

Porque quiero creer que no hay demonios. [...] son hombres quienes han vendido al hombre

JAIMe Gil de Biedma

Tras el cambio de gobierno de 1996, cuyo transcurso pacífico ratificó la consistencia de la democracia en España, narradores de toda clase empezaron a plantear en sus escritos, de forma más o menos coral, una recuperación de figuras, empeños y crímenes del pasado excluidos de las semblanzas oficiales. Por desgracia, el estruendo no tendría ningún eco en la esfera legislativa, y apenas trascendería a la esfera pública, hasta el siguiente cambio de gobierno, donde las demandas cristalizaron en la celebrada Ley de Memoria Histórica, impulsada por la ejecutiva socialista en 2007. Diez años después, la novela, el cine, el teatro o el cómic, tanto en España como en Occidente, no han dejado de transitar los más diversos géneros para (re)velar las cunetas de la memoria, formando encrucijadas de códigos narrativos muy alejadas de la esperable crónica documental, y casi siempre avaladas por las ventas y/o la crítica. La ficción en los escaparates de «novedades» se ve así impregnada por la historia - o por la Historia - al tiempo que la adapta a sus cauces y a las expectativas de un receptor que se ha acabado acostumbrando a los límites hipotéticos de cada formulación, incluso cuando estos constituyen una laberíntica madeja.

En el caso español, la herida abierta de nuestra memoria y principal foco de atención mediática, ha sido y sigue siendo la Guerra Civil. Hablar de memoria supone en la mayoría de ocasiones volver la vista hacia el conflicto 
bélico y estudiar su recuperación, a un tiempo terapéutica y traumática, desde un presente todavía en tratamiento. Para hacernos una idea de la situación en el campo editorial (y de su continuidad), basta ver el nuevo título que Isaac Rosa dio a su novela La malamemoria (1999) cuando la revisó en 2007, ¡Otra maldita novela sobre la guerra civil!, o leer la contraportada del último estudio del investigador David Becerra, La Guerra Civil como moda literaria (2015). No es propósito de este artículo, sin embargo, adentrarnos en ambos trabajos ni mostrar las entrañas del fenómeno. Antes nos interesa examinar los ribetes de su superficie, pues toda «moda» tiene patrones. Y en este marco, resulta ineludible desde el análisis cultural preguntarnos, por ejemplo, por qué la estética y las estructuras del género negro han sido tan recurrentes en los últimos «textos» que han tratado de desenterrar los sucesos más sórdidos de la Guerra y sus secuelas (Cielos de barro, de Dulce Chacón [2000], Antes de decirte adiós, de Guillermo Galván [2009], etc.); o si la conclusión fantástica de algunos relatos excepcionales funciona más allá de un apósito, un golpe de efecto, con el que subsanar las injusticias históricas de su argumento.

\section{LA DUALIDAd CONSTANTE: DOCUMENTO NEGRO, HISTORIA ROJA}

En torno a la memoria histórica, ya apuntaba José Martínez Rubio que, desde las liminares Beatus Ille (1986), de Antonio Muñoz Molina, y Galíndez (1990), de Manuel Vázquez Montalbán, «el género negro fue decisivo para la asimilación de un procedimiento vertebrador de la narración como investigación» (2015: 42) en el ámbito hispánico reciente. Puede que José Luis Sánchez Noriega desgranara algunas de las claves de esta influencia y, de paso, del éxito atemporal del noir al aventurar que quizás «el rasgo definitivo que caracteriza al cine negro sea una visión dual de lo real, la consideración numénica de que por debajo del orden aparente existe una realidad — de mayor calado y más importante- que tiene un talante sustancialmente conflictivo» (1998: 13). Es decir, sentenciaba el crítico, «el carácter negro de este cine reside no tanto en los aspectos temáticos o formales como en una metafísica, una consideración de lo real que establece un fuerte dualismo entre la visión conformista del individuo y la sociedad y una indagación más profunda...» (Sánchez Noriega, 1998: 13). Si hablamos de volver a asesinatos del pasado, extraños a nuestro contexto, no cuesta imaginar cómo este género, de marcada veta social, tiende puentes para reconocernos, para recorrer la culpa por unos escenarios reducidos (y ensombrecidos) hasta lo universal. 
Pocos mecanismos ficcionales, además, resultan más dúctiles a la hora de contar un proceso de conclusiones ásperas y sabidas de antemano que los del noir. El escritor — primer detective - se vale de unas coordenadas de tensión dramática de manual. Así, si la mentada Enterrar a los muertos (2005), de Ignacio Martínez de Pisón, curiosamente publicada en la colección «Divulgación: Historia» de Seix Barral, funciona como una «novela» (etiqueta que buena parte de la crítica le ha imputado) y no como un ensayo de indagación histórica al uso es porque su articulación responde esencialmente a la del cine negro. El meollo de la investigación consiste en averiguar quién y por qué mató a José Robles Pazos, famoso por ser el traductor al español de Manhattan Transfer, de John Dos Passos, mientras asistimos a la erosión de su relación fraternal con Ernest Hemingway, encubridor de bastantes huellas del delito. Al otro lado del tablero, si Las serpientes ciegas (2008), con guión de Felipe Hernández Cava y dibujos de Bartolomé Seguí, no reconstruyera el conflicto entre trotskistas y estalinistas en la Barcelona del 1937 por medio del personaje de Ben Koch, nos encontraríamos ante un ejemplo típico de cómic negro, y no ante un reclamo de memoria colectiva a partir de la ficción. Desde posiciones diferentes, y en un quiasmo más que curioso, en esa telaraña de volúmenes sobre la Guerra Civil de repente podemos hallar y vehicular dos textos que, sin mayor nexo aparente, confluyen en su trasvase de Historia —en este caso la historia proscrita del bando «rojo»- y cine negro. Recompongamos los hechos.

No es inocente que los dos productos se abran con la mirada panorámica de un personaje, una mirada extranjera. Es un tópico que hallamos, sin ánimo de retrotraernos demasiado, en creaciones tan distantes como las Cartas Marruecas, de Cadalso. Resulta idóneo para escarbar en las fallas de la historia que los sujetos que asumen el rol de investigadores en sendas obras sean estadounidenses y, por tanto, más imparciales y desvinculados de la convulsa realidad española de la época y de sus excesos. Como sea, los dos están sentimentalmente implicados en sus pesquisas, frente a la postura profesional de los rastreadores encubiertos de ambos textos: un Detective que busca a Ben Koch por haber incumplido un misterioso pacto en Las serpientes ciegas, y el propio autor, Martínez de Pisón, de Enterrar a los muertos. La mirada examinadora, pues, se duplica y / o se bifurca. En el caso de la novela, se expande como estrategia de credibilidad: sobre la angustia focalizada de un figurado John Dos Passos, idealista impotente en un entorno tremebundo que atraviesa para buscar a su amigo Robles, prevalece el simulado tono frío del cronista-personaje Martínez de Pisón, que se vale de las andanzas del americano para expre- 
sar su denuncia (y para ocultarse). En el caso del cómic de Las serpientes ciegas, el Detective Profesional carga con el peso del cine negro hasta casi lindar con la autoparodia (por ejemplo, en aquella viñeta donde lee las novelitas pulp en el espacio privado de la habitación de su hotel), lo que erosiona el dramatismo y la crudeza del Nueva York de la Gran Depresión para volcarlo en los sucesos en flashback donde Ben Koch, miliciano marxista, llega a la Barcelona del 37 y se encuentra de bruces, en medio de la violencia desmedida que antecede a los «Eventos de Mayo», con la utopía revolucionaria de la CNT y el POUM en el horizonte.

\section{LOS HORRORES DEL CAMINO. TEORÍAS DE LOS EFECTOS}

Hasta este momento, se ha manifestado sin tapujos una vinculación con el cine negro presente tanto en Las serpientes ciegas como en Enterrar a los muertos. Es natural que asalte la pregunta de por qué incidimos en la marca cine frente a la etiqueta, más apegada al papel, de novela negra. La respuesta radica en la fuerza de las imágenes del noir en el pensamiento colectivo. Y es que, intertextualmente, volviendo a Julia Kristeva (1978), se han grabado como un código de referencia que el espectador (el lector) proyecta de inmediato sobre un modelo conocido. Hoy en día basta con advertir dos sombras con sombrero caído en una pared neutra para saber que se avecina una muerte, lo que demuestra que en esta sociedad del espectáculo, como dijera Guy Debord (2002), ha primado la convención en las pantallas sobre la repetición en las páginas (al menos en lo que a crimen se refiere). No hay que olvidar, además, que una amplísima mayoría de los receptores potenciales de ambas obras ha tenido acceso al fotograma, de un modo más o menos forzado, dada la recurrencia machacona de su uso, pero no necesariamente se ha interesado por la lectura de sus casos. La imagen, en los tiempos modernos, vale más que mil palabras...

$\mathrm{Y}$ en lo que toca a las truculencias de una guerra, la equivalencia se queda corta. El horror se ha de visibilizar, es parte de su naturaleza estética. No por casualidad el recorrido que dibuja Martínez de Pisón en la novela se asemeja a un retablo, una estructura de paneles, calculadamente cargada de detallismo gráfico en sus cotas más estremecedoras. Por ejemplo, en los párrafos dedicados al exilio masivo de los republicanos españoles hacia Francia donde, a manera de un plano secuencia, caminamos junto a

Mujeres que para salvar algo de su guardarropa llevaban puestos tres o cuatro vestidos, niños con la cabeza rapada a causa de los piojos, ancianos e inválidos 
que se ayudaban de bastones y muletas, hombres envueltos en mantas y capotes que arrastraban grandes fardos y que corrían en busca de cobijo en cuanto aparecían los bombarderos alemanes e italianos... En medio de aquella marea humana se veían carros cargados de colchones, muebles, bultos de ropa (...). De vez en cuando algún coche o camión atestado de gente conseguía abrirse paso, y al poco rato lo volvían a encontrar en la cuneta de la carretera, estropeado o sin combustible o reventado por una bomba (Martínez de Pisón, 2006: 186).

El apoyo en la imagen es tan claro que el autor no recurre a la descripción de los exiliados, sino a la enumeración de sus tipos. Somos nosotros, como lectores, quienes completamos la información (el boceto) a partir de las fotografías de archivo que almacenamos en la retina. Dicho mecanismo se canaliza, siguiendo la terminología del profesor Jaume Peris (2011), como un efecto de memoria que nos retrotrae a una realidad registrada e interiorizada como propia, tras haber sido aprehendida en decenas de discursos. ${ }^{1}$ En paralelo, la extracción de datos que pertenecen o recuerdan al ámbito documental supone una constante del formato de investigación histórica que simula Enterrar a los muertos, con lo que se genera un subsiguiente efecto de realidad, ahora en los términos clásicos de Roland Barthes (1987). Martínez de Pisón, previsiblemente, no va a agujerear esa escenografía veraz-documental que ha construido. Lo máximo que se permite es un providencial giro final en la trama que asemeja más que nunca la estructura del libro al montaje pespuntado de un thriller, por lo sorprendente de su última revelación, que contribuye a mantener hasta las últimas páginas el estado de angustia ante la fatalidad.

La propuesta de Las serpientes ciegas, sin embargo, no se fundamenta en un artificioso giro argumental, sino en una dislocación completa del sentido de la narración: después de exponer el horror terrenal, rigurosamente humano, de los ya anunciados «Eventos de Mayo», lo fantástico hace su aparición en las viñetas finales. Y lo hace «como una rajadura, una irrupción insólita de lo imposible en un mundo ficcional que funciona según las leyes físicas y regularidades de nuestro paradigma de realidad, cuyo efecto es atemorizar a los

1. Entendemos el efecto de memoria tal y como propone Peris Blanes: «en múltiples novelas, películas, fotografías y discursos culturales de los últimos años que tienen como objeto el pasado reciente, podemos hallar algo similar: elementos formales (palabras, enfoques, tonos...) que carecen aparentemente de valor narrativo y que podríamos considerar detalles inútiles o superfluos pero que tienen, en realidad, una función textual muy clara: inscribir el universo de la representación en ese espacio magmático y a veces indeterminado, a medio camino entre la subjetividad y la referencialidad, entre el mito y la historia, que es el espacio de la memoria (...). En general, podríamos señalar que los elementos que producen un efecto textual de memoria son aquellos que inscriben el universo diegético en un ambiente o una atmósfera que el receptor identifica claramente con una representación del pasado no directa, sino filtrada por el tamiz de la memoria» (Peris Blanes, 2011: 42-43). 
personajes, al narrador y/o a los lectores, con la finalidad de desestabilizar y cuestionar la idea socialmente compartida de "realidad"» (Molina Gil, 2015: 178). ${ }^{2}$ Sin salir del marco del destinatario, la brecha argumental de Las serpientes ciegas — que desvelaremos en el siguiente apartado- produce así un efecto de miedo metafísico, entendido según los parámetros de David Roas en tanto impresión «propia y exclusiva de lo fantástico (en todas sus variantes) (...) que si bien suele manifestarse en los personajes, atañe directamente al receptor, puesto que se produce cuando nuestras convicciones sobre lo real dejan de funcionar» (Roas, 2011: 96). De ahí que convenga detenerse un poco más en las representaciones de la realidad en guerra de las que se nutren ambos textos.

Los escenarios de Enterrar a los muertos, coincidentes en buena parte con los del cómic, dirigen sus esfuerzos a la exhumación de un estado de terror panóptico, el que impusieron los cuerpos de seguridad e inteligencia dirigidos desde Moscú. Si repasamos los imaginarios más temibles de la novela a la luz de Las serpientes ciegas, se podría pensar — afilando la contraposiciónque los «Eventos de Mayo» no son demasiado relevantes para revelar la mano ejecutora de José Robles; la verdad, no obstante, es que «preferimos saber los motivos por los que asesinaron a Robles en ese clima violento de la Guerra Civil en la capital provisional de la República, mejor que quien lo ejecutó, porque nos daría una visión más compleja de esa figura» (Martínez Rubio, 2015: 174). Su atentado actúa como una clavija, parece el pretexto que permite a Martínez de Pisón componer una microhistoria sobre el inicio de las masacres estalinistas en España y en la propia Unión Soviética. Esa es la tesis fundamental que rezuma Enterrar a los muertos, y que el autor acabaría explicitando en varias entrevistas posteriores: «Las causas concretas son difíciles de precisar. En mi libro propongo varias hipótesis. Su asesinato es, en todo caso, una especie de prólogo a esa purga de los militares soviéticos» (en Castro, 2005). De hecho, en la última parte de la novela, el «Apéndice», que se presume cajón archivero de todo lo referido, Martínez de Pisón no nos hablará sino de las contradicciones oficiales en el sumario a los trotskistas y de sus implicaciones literarias en editoriales como Cenit (donde se publicó la traducción de José Robles de Manhattan Transfer), y de cómo se combinaron tantas veces los papeles de víctima y verdugo.

Y en ese proceso de descubrimiento de roles la mirada extranjera antes aludida excedió su papel como tópico narrativo. En un contexto de tanta ten-

2. Esta definición parte de los estudios anteriores de Béssiere (2001), Caillois (1966), Castex (1951), Ceserani (1999), Roas (2001) y Vax (1960). 
sión entre fascismo-nazismo, comunismo y capitalismo incipiente, la Guerra Civil —no está de más recordarlo- llamó y concentró a todos los frentes culturales y políticos del momento, reclamando de ellos una toma de posición ideológica y vital. El Hotel Florida en Madrid, donde se alojó el grueso de los intelectuales de izquierdas durante la contienda, funcionaría, de hecho, como símbolo de paso, una minúscula estación internacional que cambió visceralmente el rumbo de la producción de muchos de ellos (Dos Passos o el mismo Hemingway). No es de extrañar, por tanto, que las ficciones pioneras a la hora de sumergirse en los frentes de tensión más crudos de la izquierda en la Guerra Civil hayan venido firmadas históricamente por extranjeros que han narrado desde un espacio ajeno los espantos y las vergüenzas de la contienda.

Una de las películas recientes más aclamadas en este sentido fue la precursora Tierra y Libertad del irlandés Ken Loach, quien en 1995 pondría sobre la mesa, tras muchos años de olvido, el delicado tema de los «Eventos de Mayo» de 1937, momento en que la legalidad republicana, escoltada por los partidos soviéticos estalinistas de España, se enfrenta y reprime el ideario revolucionario trotskista del POUM (y otros partidos). En el film se cuenta la desdichada historia de un voluntario británico, David, que, igual que Ben Koch en el cómic de Cava y Seguí, llega a Barcelona y lucha junto al POUM, se enamora, como Ben, de una miliciana, que muere también a manos de los represores, y se alista, como Ben, en las Brigadas Internacionales de Aragón. La primera vez, no obstante, que este tema tuvo cobijo en la pantalla fue en un documental francés, Mourir à Madrid (1963), de Frédéric Rossif. Y, desde luego, si este conflicto ha enraizado en el imaginario literario colectivo y ha tenido repercusión a gran escala ha sido gracias a Homenaje a Cataluña (1938), de George Orwell, tan repudiado en su momento por la izquierda oficial. En su epílogo, el escritor británico llegaba a hacerse eco del titular lapidario del Daily Worker del 21 de junio, cuando el POUM fue definitivamente ilegalizado, acusado de servir a los intereses franquistas. Adjuntamos las líneas iniciales de la mendaz noticia, tan impactante hoy:

\section{TROTSKISTAS ESPAÑOLES CONSPIRAN A FAVOR DE FRANCO}

Tras la detención de un elevado número de destacados en Barcelona y otros lugares..., han llegado a conocerse durante el fin de semana algunos detalles de uno de los casos de espionaje más horrendos que se hayan dado en una guerra y la más espantosa traición trotskista hasta el momento... Los documentos que obran en poder de la policía, más la confesión completa de no menos de doscientos detenidos, demuestran... (Orwell, 2010: 244). 
No es trivial, por tanto, que el Daily Worker tenga una mención especial nada más comenzar la trama de Las serpientes ciegas: el encargado del hotel donde se aloja el Detective reseña que una lámina del «Guernica» se publicó a bombo y platillo en ese diario, que él mismo repartía, y gracias al cual conoció a Ben Koch. En la Nueva York del año 1939, la sombra de la Guerra Civil sale a recibirnos en las primeras cinco páginas, de la mano de un primerísimo plano del cuadro de Picasso, donde la mujer incendiada alza sus brazos al cielo. Hila con finura el cómic las pinceladas documentales que reproducen la atmósfera coetánea del relato. Otro efecto de memoria este que, siguiendo el concepto ya expuesto, empapa toda la narración... y todo el dibujo: Bartolomé Seguí sustituye el blanco y negro habitual de sus creaciones por tibios grises y marrones con agresivas pinceladas rojas que enrarecen figuras y espacios; una imagen desgastada, como producto de otro tiempo, de otras coordenadas, evocada desde un presente incierto. Las huellas, no obstante, indican claramente el sendero: las viñetas del cómic están perspicazmente empapeladas de cartelería histórica. El POUM irrumpe pronto con su mensaje «Treballadors El POUM us espera» (Hernández Cava y Seguí, 2008: 35), casi una trágica imprecación a lo que será el desarrollo del capítulo central por la Barcelona del 37, que con acierto se remata con otro cartel del POUM (punto de fuga para la vista en la viñeta) que reza: «POUM fins a vèncer o morir» (2008: 42).

\section{El CAMINO DEL HORROR: LA RUPTURA FANTÁSTICA}

«En el cine negro», decía el director y teórico de cine Noël Simsolo, «las sombras y luces persiguen a unos seres que se debaten en un no man's land funerario. Encontramos un ceremonial de iniciación durante el cual el espectador cruza el espejo de la ficción y ve cómo sus propios demonios salen a su encuentro» (2009: 16). Sánchez Noriega incidiría en la carga funesta de tal panorama al señalar que el género presenta un "parentesco incuestionable con la gran tradición de carácter trágico, desde los griegos a Shakespeare» (1998: 14). No hay redención en el cine negro; aunque el detective pueda acabar junto a la chica y a salvo después de los últimos disparos, se ha contagiado de una maldad de la que no puede desquitarse. En el caso de Enterrar a los muertos, desde ese título que nos hace referencia a un «abajo», Martínez de Pisón nos obliga, impelido si se quiere por la Historia, a ser testigos de un tránsito por los infiernos. El recreado Dos Passos se somete en manos del narrador a una suerte de via crucis ideológico por los abismos de una memoria condenatoria y condenada del bando republicano: la referida criba promovi- 
da desde la URSS por Stalin que corrompió, cuando no acalló definitivamente, la voz lejana de los viejos camaradas que creyeron en la posibilidad de la Revolución en España. De ser un enamorado del país y de sus costumbres populares, inclinadas a ese anarquismo que según él estaba en el ADN del ser español, Dos Passos (que en el año 1923 había publicado esa oda titulada Rocinante vuelve al camino) pasaría a repudiar, primero, la tierra (España, a la que no regresaría hasta dos décadas después) y más tarde, la causa.

El norteamericano vio de cerca a los demonios intestinos de la Izquierda, personados en la disputa irreversible con su homólogo, corresponsal de la contienda para la North American Newspaper Alliance, Ernest Hemingway. Qué mejor filtro para representar sus fisuras que el noir, habitado por «seres humanos en el límite (...) vidas trastocadas por situaciones que les arrastran a cumplir un destino» (Sánchez Noriega, 1998: 18). Un destino donde no caben héroes. Robles muere en una checa; los estalinistas son liquidados tras su vuelta a la URSS; el POUM, parafraseando a Orwell, se convierte en la flor del proletariado pisoteada por todas las policías de Europa; Hemingway no convence, ni vence. Él es, por emplear una palabra clave en el género, el gran «sobornado» del conflicto. En cuanto a Dos Passos, huye - pesaban sobre él varias amenazas de muerte si no lo hacía-, pero ya no encuentra la paz en los Estados Unidos (no está más de seis meses en el mismo espacio) ni se antoja inocente para el lector. Si acaso, lo compadecemos. Compadecemos su peregrinaje, su fracaso a la hora de destapar la verdad sobre el caso Robles, su silenciamiento literario, y al término del camino, a pesar de todo, condenamos el vuelco irremisiblemente conservador y paranoide de su trayectoria vital posterior, que niega el veredicto plácido para esa crónica atormentada que es Enterrar a los muertos. Así evoluciona el cine negro: no tanto hacia oposiciones binarias de Bien/Mal, sino de Inocencia/Culpabilidad. Y es que, según concluye Sánchez Noriega, «en el cine negro [el conflicto] es esencial a la realidad [no nace de un desequilibrio concreto] y acaba negando ese orden, de ahí la imposible reconciliación y la inexistencia de cualquier happy end» (1998: 14).

Al menos la venganza sí será consumada en Las serpientes ciegas: Ben Koch prende fuego al miliciano de la URSS, Curtis Rusciano, que había traicionado al partido y le había cortado literalmente la garganta en la Batalla del Ebro; pero esta suerte de redención, de revanchismo de la memoria, no tiene cabida en el presente de post y de preguerra (el argumento se ambienta en 1939) de los vivos. En el último giro argumental del texto, el Detective Profesional innominado, en perpetuo rojo, que se había definido — cliché del Borgart torturado- como «un enviado del infierno» (Hernández Cava y Seguí, 
2008: 65), desaparece en la viñeta final hacia ese inframundo de origen junto con el redivivo Ben Koch — que se había fugado de allí-, detonando un efecto fantástico que obliga a releer el cómic desde otro prisma. Las típicas coletillas negras, como «en eso consiste mi trabajo: en capturar a los insinceros para hacerles ver que no se puede dar en vano la palabra propia» (2008: 5) o «no sé qué barbaridad cometiste en Detroit, Ben Koch, para haber sido condenado al infierno» (2008: 72), cobran así un sentido diabólicamente fidedigno al término de la escena, cuando ambos se encuentran «en el corazón de Harlem apurando nuestros últimos minutos sobre la tierra» (2008: 72), rodeados de gente poseída por el ritmo del jazz. «Queda el hueco de la danza sobre las últimas cenizas», advertía García Lorca en su poema «Norma y paraíso de los negros» (2006: 125) Aquí el prisma se invierte iconográficamente: norma e infierno; infierno y norma. Una dirección esta que el simbolismo de las imágenes refuerza: pulula un gato negro por la habitación roja del Detective, como si se sintiera imantado por su presencia pelirroja, siempre como un voyeur, con el pelo encrespado formando dos cuernos. Ben Koch, también con el pelo levantado, escarlata, dotado de unas facciones triangulares, parece casi un trasunto desdoblado del propio Detective. Como si los dos encarnaran, cada uno desde su trinchera, aquella metáfora de «la Guerra como Infierno». Ambos, en un movimiento contrario al de Enterrar a los muertos, se han levantado desde su desconocido averno para resarcirse del agravio de su historia y, de paso, reclamar e intervenir en el recuerdo de ese trauma de la izquierda antes y mil veces aludido. Y luego, han caído de nuevo, se han esfumado, como si nunca hubieran vuelto a violentar sus calles.

Es muy significativo que los primeros vistazos a la Nueva York de la Gran Depresión del cómic desembocaran, tras el paso del Detective por una concurrida calle, en una toma en tonos arcillosos de la ciudad despoblada (2008: 5), como un preludio redondo de su pesadillesco colofón. Con estas viñetas Cava y Seguí homenajean, por otra parte, la apertura de otro texto de satánica revelación final, la película El corazón del ángel (1987), del británico Alan Parker, en la que un detective privado de baja estofa, interpretado por Mickey Rourke, se sumerge en los ambientes estadounidenses más lóbregos de los años 50 para encontrar a un enfermo psiquiátrico desaparecido, mientras a su alrededor se van sucediendo las ejecuciones de las personas implicadas. Un viaje al corazón de las tinieblas (amén a la referencia de Joseph Conrad con la que juega el título) que culmina cuando el desesperado detective acude a explicar la resolución de los crímenes a su adinerado contratante, Lu Syfer (Robert de Niro). Es entonces — espejos en la sala mediante- cuando 
con punzante ocurrencia Lu Syfer se revela como el mismo Lucifer que quiere cobrarse el alma del detective (verdadero homicida inconsciente de todo el proceso).

No es la fotografía de apertura, después de todo, lo único que el cómic toma prestado de la película. La danza negra y la música de jazz actúan, asimismo, como catalizadores rituales que anticipan la aparición demoníaca arrebatada y, en términos generales, el ejercicio noir del film orbita en los mismos círculos que la obra de Cava y Seguí. De este modo, la condena por los pecados pasados, la deuda del protagonista para con la humanidad, ha de saldarse también fuera de los límites físicos y morales del mundo «real». Y, hasta cierto punto, los esquemas del cine negro favorecen la infiltración de tal elemento imposible. Si se revisa desde esa óptica la cita de Sánchez Noriega que páginas atrás adjuntamos para introducir la problemática del género, es inevitable replantearse el sentido de la metafísica al que aludía. «El carácter negro de este cine», decía, «reside no tanto en los aspectos temáticos o formales como en una metafísica, una consideración de lo real que establece un fuerte dualismo entre la visión conformista del individuo y la sociedad y una indagación más profunda...» (Sánchez Noriega, 1998: 13); una indagación del alma humana y de las fronteras de lo real (y del miedo) que nos abisman. En definitiva, una reflexión epistemológica sobre el ser y un cuestionamiento ontológico de la realidad; detalles ambos inherentes a cualquier teoría y práctica de lo fantástico.

Sucede, además, que el cómic, como formato generador de realidades (y fronteras), tiene unas condiciones para conducir y desarrollar la aparición de lo fantástico más aptas que otros medios. De este modo, frente a la atmósfera necesariamente impresionista y oscurecida de los mugrientos decorados urbanos de El corazón del ángel, la libertad del papel en blanco permitió a Cava y Seguí dotar a Las serpientes ciegas de una ambientación completa, que si bien imitaba los remedos cinematográficos y los planos propios del género en el que se movía, también superaba algunas de sus limitaciones - como iluminar cualquier espacio sin miedo a revelar que sus contornos son de cartón piedra-. Y es que como glosó Antonio Candeloro al hilo de la publicación del volumen El universo fantástico del cómic, de Luis Gasca y Román Gubern:

El cómic puede crear mundos todavía más «alternativos» al nuestro con respecto al cine: no hace falta mucho dinero ni la participación activa de numerosas personas para poder crear otra realidad posible y potencial, pues es suficiente con una hoja en blanco y un lápiz. En este sentido el cómic ha explotado 
con desenvoltura y extrema libertad el lado «fantástico» de la imaginación humana, entendiendo con este término un sinónimo del sintagma aristotélico «verdad poética», esto es, algo que no existió ni ocurrió pero que habría podido existir u ocurrir, según las leyes básicas de la necesidad y la verosimilitud que regulan y configuran lo que el Estagirita define en su Poética como mythos, o sea, «relato» (Candeloro, 2016: 275-276).

Así las cosas, lo que propusieron Gasca y Gubern en este recopilatorio de coreada aparición, El universo fantástico del cómic (2015), fue una revisión de los habitantes más famosos de esos mundos posibles, desde los dioses grecorromanos hasta los monstruos producidos por la radiación, a lo largo de la historia del cómic. Dentro de esta nómina aparecen también los dos arquetipos clásicos que encarnarán, de hecho, los protagonistas de Las serpientes ciegas, «los demonios», en especial los provenientes de la tradición cristiana, y «los fantasmas». El tratamiento de estos arquetipos por parte de Cava y Seguí responde ya a técnicas posmodernas, en consonancia con las líneas maestras de la narrativa fantástica — entendida esta vez en su sentido teórico más específico- del siglo xxI, expuestas, entre otros críticos, por Juan Jacinto Muñoz Rengel (2010). Si algo destaca, no obstante, en el desglose —o decálogo- de motivos fantásticos que emprendió Muñoz Rengel fue que hizo aparecer dos veces a los «fantasmas». Primero se refirió a ellos como revulsivos tradicionales que cuestionaban la naturaleza del mundo, pero más adelante se hacía eco de su capacidad para cuestionar también la naturaleza del yo en obras contemporáneas, cuando se invierte la perspectiva y «el fantasma y el protagonista se identifican. Este cambio de punto de vista nos permite situarnos al otro lado, en la dimensión de lo oculto. Lo fantástico somos nosotros» (Muñoz Rengel, 2010: 10). Esa sería la gran «vuelta de tuerca» de películas contemporáneas como Los otros (2001), de Amenábar, ambientada en la realidad espectral de 1945. Con parecido efectismo final, aunque con distintas pretensiones, el personaje de Ben Koch, sobre el que habíamos depositado nuestra empatía como espectadores, participará también de este recurso al descubrirse como un fantasma, surgido de entre los muertos de otra guerra.

Como sea, en el terreno de las ficciones recientes sobre la memoria, el carácter realista de las mismas sigue siendo mayoritario. No solo eso, en ocasiones llegamos a tener la sensación de que es necesario que así sea. Al fin y cabo, orillamos un tema de indiscutible seriedad en el que el artificio fantástico se concibe como un arreglo un tanto frívolo o juvenil. Ocurre, sin embargo, que el cuestionamiento de las condiciones de lo real que plantea lo fantástico 
-igual que lo grotesco $\mathrm{C}^{3}$ - puede tener una impronta absolutamente revolucionaria. No en vano, «el relato fantástico pone al lector ante lo sobrenatural, pero no como evasión, sino, muy al contrario, para interrogarlo y hacerle perder la seguridad frente al mundo» (Roas, 2001: 8). Quizás sea este el punto de partida que mejor nos ayude a destapar las implicaciones que laten en Las serpientes ciegas, pues lejos de ser un recurso complaciente con el que rematar la obra por medio de un deus ex machina que asombre al lector, su despliegue opera sobre la visión ideológica de la Guerra Civil que los autores buscan transmitir.

La fuerza, por otro lado, de la interpretación realista tiende a reubicar el componente fantástico, en los ojos del crítico, en una apacible esfera metafórica o alegórica. Sucede así en la agradecida reseña que el también dibujante Álvaro Pons dedicó a Las serpientes ciegas con motivo de la concesión del Premio Nacional de Cómic 2009 a la obra. «En un análisis casi cruel», elucubra Pons, «Cava parece plantear que las ideas son utopías destinadas a ser manipuladas y destrozadas por un ser humano incapaz de separarse de sus egoísmos y avaricias. Da igual la geografía y los momentos: la ingenuidad de quien defiende un ideal, muchas veces sin ni siquiera llegar a comprenderlo, será siempre derrotada por una perversión que es innata al ser humano. El diablo siempre vencerá, es el destino» (2009). A nivel ideológico, las palabras de Pons sobrevuelan implícitamente un circuito teórico de sobra conocido según el cual los metarrelatos fundacionales ya no tienen cabida en la Posmodernidad; no existe la posibilidad de generar discurso utópico en nuestro horizonte político. En la pista de la tan comentada cita de Bruce Franklin (1979), popularizada por Fredric Jameson (1999), es más sencillo imaginar el fin del mundo que el fin del capitalismo. Y en lo que respecta a su nivel semiótico, Pons no está sino glosando el tono más desengañado y herrumbroso del cine negro clásico que perfila el cómic. Es suficiente repasar las traducciones al castellano de los títulos más emblemáticos de los años 40 y 50 para introducirnos en el desencanto al que nos aboca. De este modo, el crítico parece predicar la victoria universal de la «perdición» o la «perversidad» como estados natural y moral de la convivencia del hombre (y en sus sombras se integran, de hecho, la traición cainita dentro del Frente Popular o los intereses contrapuestos de dos amigos a la hora de ocultar o demostrar un asesinato en la novela de Martínez de Pisón). El efecto fantástico, sin embargo, no despega la trama de Las ser-

3. Retomamos en este punto la máxima de Kenneth Burke sobre la capacidad subversiva de dicha estética: «Allí donde el humor tiende a ser conservador, lo grotesco tiende a ser revolucionario» (en Ziomek, 1983: 16). 
pientes ciegas del suelo histórico y concreto de la Guerra Civil en el que se erige; no se cimienta sobre lo real como un mecanismo de sustitución, sino que lo expone para que el lector lo cuestione libremente. Y si ello puede funcionar es porque en nuestra sociedad no resultan aún comunes muchos de los pormenores más brumosos de la contienda, en este caso, la aterradora caza a los milicianos trotskistas por parte de los bloques estalinistas. Reside aquí la subversión fantástica, tan naïf y socorrida —en apariencia- como desenterrar la figura del Diablo, y pese a ello enormemente poderosa para reinterpretar el sentido del cómic y, por ende, ese apartado de nuestra memoria histórica.

Ello no implica, por otra parte, que el poso fantástico rompa la atmósfera detectivesca punteada a lo largo de toda la trama. Ya Tzvetan Todorov relacionaba ambos géneros en su ensayo pendular Introducción a la literatura fantástica, al hilo de la figura híbrida de Poe como precursor de la «conclusión imposible» en los relatos de misterio, bien protofantásticos bien policiacos (germen de la precisión negra posterior):

Aclaremos la naturaleza de esta relación. La novela policiaca de misterio en la que se trata de descubrir la identidad del culpable está construida de la manera siguiente: por una parte, tenemos un buen número de soluciones fáciles, a primera vista tentadoras, que resultan falsas una tras otra; por otra parte, hay una solución absolutamente inverosímil a la cual sólo se llegará en el desenlace y que resulta la única verdadera (...). Basta, pues, que en la novela policiaca esa segunda solución sea tan difícil de descubrir hasta el punto en que desafíe a la razón para que estemos dispuestos a aceptar la existencia de lo sobrenatural más que la ausencia de otra explicación (Todorov, 2001: 73).

Este diálogo entre cine negro y literatura fantástica, aunque sea en unos términos no del todo coincidentes con los de Todorov, se continúa actualizando en obras de flamante aparición. La santería vudú que exploraba El corazón del ángel salpica, sin ir más lejos, nuevas pesquisas sureñas, como la que arrastra la trama de la primera temporada de True Detective (Pizzolato, 2014). ¿Qué es la ciudad de Carcosa, templo ritual de sacrificios humanos, sino el lugar común que ata en un mismo imaginario las ficciones de Ambrose Bierce (primer descubridor), Chambers, Lovecraft y Pizzolato, cerebro de la serie? Es muy significativo que cuando la cámara adopta en la ficción el punto de vista del personaje interpretado por Matthew McConaughey, se manifieste lo fantástico a través de la naturaleza desgastada de ese entorno pantanoso americano, en permanente decadencia. Así ocurre en el segundo capítulo de la primera temporada cuando vislumbramos - McConaughey de espaldas, cual 
figura surrealista de René Magritte - que una bandada de pájaros toma la forma de la espiral dibujada en el cuerpo de las víctimas.

La relación tampoco será ajena al ámbito nacional. Se ha perpetuado precisamente en una película que, desde su estreno, no ha parado de ser asociada con True detective. Hablamos de La isla mínima, de Alberto Rodríguez (2014). El director sevillano consigue proyectar un drama sureño en torno a las marismas del Guadalquivir, que devienen pronto en fosa común donde se acumulan las vergüenzas de la Transición Española que nunca tuvieron repercusión mediática. En tales latitudes, una santera le imputa a un antiguo policía de la Brigada Político-Social (interpretado por Javier Gutiérrez) que «los muertos le están esperando». La cita cobra en el limbo gris y estancado del film un doble sentido, que incluye tanto la alusión a su pasado de torturador durante la Dictadura como a la fatalidad que parece cernirse sobre él. Y premeditadamente el presagio se materializa a través de la aparición casi «sobrenatural» (en el sentido etimológico: por encima de la naturaleza, impuesto sobre el paisaje) de coloridos pájaros que rompen la escenografía y parecen interrogar, como reflejos de su culpa, al nocturno personaje, que — descubrimos al final- recibía el apodo de El Cuervo. En torno a esto, y regresando a Las serpientes ciegas, podemos recuperar una viñeta de Cava y Seguí en la que inmensas ristras de pollos desplumados apilados en una trastienda judía (2008: 17) vaticinan, no ya el Holocausto, sino la misma traición de los estalinistas, al vincularse con las aciagas palomas que despiertan con su zureo a Ben Koch durante su aventura en Barcelona (2008: 37). En el imaginario occidental moderno, no es extraño que las aves, transmisoras clásicas de un mensaje, se trasmuten a veces en improvisados heraldos de la muerte, la destrucción o la locura. Basta con volver las alas a la literatura de Poe, a la pintura de los hermanos Wyeth, al primer cine negro de Fritz Lang o, por supuesto, a Hitchcock.

\section{LAS OBRAS EN SU CONTEXTO: PANELES Y FANTASMAS}

Por más que John Dos Passos asegurara, tres décadas después, que presagió el fracaso de la República cuando dos palomas no pudieron, en un mitin del año 33, levantar el vuelo por el calor y el largo encierro (Dos Passos, 1984: 270; Martínez de Pisón, 2006: 44), sobra insistir en que ninguno de estos elementos, en lo que respecta a la búsqueda de Robles, atraviesa Enterrar a los muertos, ni tampoco la mayoría de narraciones hermanadas con ella, como la tan trabajada Soldados de Salamina (2001). Se podría pensar que el formato no- 
velado, limitado a la potencia de lo «leído», restringe las opciones de sorpresa y credibilidad de los efectos fantásticos, máxime cuando hablamos de productos construidos a partir de una investigación veraz, que tiende a lo autoficcional. Sin embargo, y a pesar de las oportunidades que ofrece la combinación de imagen y palabra, los cómics tampoco se han desviado demasiado de esta ruta de ineludibles tonos realistas. ${ }^{4}$ Fue pronto, en 1977, cuando Carlos Giménez abrió la veda gráfica de la memoria con los episodios iniciales de Paracuellos (Giménez, 2011a), una historieta costumbrista sobre unos niños que vivían en los hogares de Auxilio Social durante la postguerra. Hoy en día está más que asumida la relevancia del tema en el panorama. Como afirmara Viviane Alary, «los críticos no vacilan en afirmar que, sin esta dimensión de "relato de la memoria", la novela gráfica no sería lo que es hoy» (2011: 218). Y cómics como El arte de volar (Altarriba, 2009) o 36-39 Malos tiempos (Giménez, 2011b) avalan esa tesis, que ha contado con un respaldo notable tanto de la Academia como de los sectores más especializados. No está de más recordar que Las serpientes ciegas fue Premio Nacional de Cómic 2009 (galardón que en su faceta narrativa alcanzaría también La buena reputación de Martínez de Pisón en 2015).

Apenas tres años tardarán Felipe Hernández Cava y Bartolomé Seguí en adentrarse en las ruinas de otra contienda, o de su simulacro: la Guerra Fría. ${ }^{5}$ Ella es la gran protagonista de la continuación natural de Las serpientes ciegas, demiúrgicamente titulada Hágase el caos (2011). Alrededor de un plan para eliminar al mariscal Tito, este nuevo cómic entreteje toda una trama de espionaje donde la ceguera se ha vuelto una constante y ya no quedan serpientes, solo títeres. La cuestión es que tampoco queda ningún rastro o señuelo fantástico en su desarrollo. Las serpientes ciegas se confirma así como una rara avis, una isla, en el panorama de creaciones que se adentran en la recuperación de la memoria histórica, incluso para sus autores.

Sí persisten, por otra parte, las estrategias del cine negro. En una espiral infinita, volvemos a reconocer los escenarios encasillados: coches, persecucio-

4. Para echar un vistazo a las meritorias excepciones de autores (como David Rubín, Andrés Leiva o Paco Roca) que han desafiado esta tendencia en las últimas décadas recomendamos el artículo de Josep A. Rom Rodríguez (2010).

5. Curiosamente, la exhumación del conflicto yugoslavo ha sido recurrente en la ficción española de los últimos quince años (quizás, primero, por la implicación del Estado en el enfrentamiento serbocroata de los años 90 y, segundo, por la relevancia de su huella en la Europa contemporánea — es el último genocidio ideológico en territorio europeo-). Por mencionar una contribución señera, la novela Cita en Sarajevo, de Francesc Bayarri (2009) recrearía la historia Ilja Stanic, presunto agente secreto de la Yugoslavia de Tito, que asesinó brutalmente en los años 60 en Carcaixent, al general Luburic, croata pronazi, director del campo de exterminio de Jasenovac. He aquí otra historia diseñada a través y a raíz de un crimen, y que, como parte de la crítica ha señalado, se infiltra sin miramientos en esa nebulosa que es el género negro. 
nes, retrospectivas de la ciudad, reflexiones en picado, tiroteos, planteamientos magistrales y desengañados, tugurios de hotel... Los mismos que sellaban las páginas de Las serpientes ciegas, imbuidos de un claroscuro caravaggista, esencial del género, o los que decoraban los entramados madrileños de Enterrar a los muertos, con sus dos grandes núcleos para periodistas e intelectuales extranjeros, el hotel Florida y el hotel Victoria, «ese nido de corresponsales, agentes gubernamentales, espías, traficantes de municiones y mujeres misteriosas», que cuando Dos Passos vuelve a España años después hallará «vacío y silencioso» (Martínez de Pisón 2006: 150). Así lo confiesa en sus pseudomemorias Century's Ebb: The thirteen Chronicle, publicadas en los años 70. Una atmósfera parecida a la que evoca, con cierta bilis, George Orwell cuando describe la situación en su Homenaje a Cataluña, acabado en el año 38:

Dentro del hotel, entre la heterogénea muchedumbre que, salvando algunas excepciones, no se había atrevido a asomar la nariz, se había ido gestando un horrible clima de suspicacias. Ciertos elementos afectados por la fiebre del espionaje iban de aquí para allá, susurrando que todos los demás eran espías de los comunistas, o trotskistas, o anarquistas, o lo que se les terciara. El gordo, que era agente ruso, arrinconaba por turno a todos los refugiados extranjeros y les explicaba con convincentes argumentos que todo aquel asunto era un complot anarquista (Orwell, 2010: 157).

Sin embargo, lo que en Orwell era un intento de apunte fiel de lo que él mismo había vivido en España, en Dos Passos responde ya a un lenguaje asimilado individual y socialmente en el que se mezcla lo pasado («las cosas», como decía Valle-Inclán, «son como se recuerdan») y lo visualizado tantas veces en la butaca. Orwell no puede hablar desde el cine negro, porque apenas es una intuición, una temática expresionista más en el drama bélico de 1938; Dos Passos, evidentemente, no puede escapar de ese esquema, y tampoco sus lectores contemporáneos, que han sido testigos de Perdición, Laura, La mujer del cuadro, Historia de un detective y El halcón maltés... Películas todas estrenadas en Francia en 1946 y cuya proximidad avivó que la crítica acuñara avant la lettre aquella etiqueta de film noir. Martínez de Pisón, por todo ello, no recoge ni amalgama con inocencia los testimonios, deslavazados en el tiempo, de John Dos Passos, de George Orwell o de Arturo Barea ${ }^{6}$. Con magisterio,

6. «Convites en el bar del Gran Vía, convites en el bar Miami, convites en el bar del hotel Florida. Aparte de algunos "veteranos" de Madrid, embebidos en el trabajo, tales como George Seldes y Josephine Herbst, los periodistas y los escritores extranjeros se movían en un círculo de ellos, con una atmósfera suya, rodeados de un coro de hombres de las Brigadas Internacionales, de españoles ansiosos de noticias y de prostitutas atraídas por el dinero abundante y fácil» (Barea: 2001: 291). 
halla en ellos el latido de una emoción inequívocamente asociada al código detectivesco al que nos quiere retrotraer, y la explota hasta generar la ilusión dramática suficiente para escapar de la historiografía, para dotar de intriga al registro de su crimen. No será hasta el último tramo de la novela cuando Martínez de Pisón se decida a desenterrar una de las voces, quizás «La voz», que le transmitió los entresijos de todo el proceso (y de todo el sufrimiento), la hija de José Robles, Miggie. Hay momentos de larga angustia para el lector que no existirían si la informante hubiese sido desenmascarada con anterioridad. De un modo similar, pero con dejes más retorcidos, actúa el autor cuando aborda las desdichas del segundo hijo de José Robles, Coco (condenado a muerte por el Régimen franquista, transmutado en preso político e interno en múltiples prisiones durante años), pues no revelará hasta dos páginas antes del final que, contra todo pronóstico, logró sobrevivir a aquellos tormentos para reencontrarse en México con su hermana y su nueva familia.

En otro orden de cosas, y como cierre al repaso por estos trucos de montaje, la arquitectura de Enterrar a los muertos se antoja muy diferente de otras ficciones con las que suele compartir estantería, como la citada Soldados de Salamina o el film Las 13 rosas, de Emilio Martínez Lázaro (con guión de Martínez de Pisón). A poco que se escarbe en su estructura descubrimos las costuras de un disimulado retablo que desborda, por su sentido plástico, el lenguaje del texto o de la pantalla para acercarse precisamente al de la historieta. Cada corte no semeja un acto tanto como una viñeta. Y la disposición en retablo a la que se somete la obra exige una viñeta axial y de mayor tamaño. El autor focalizará en ella el quién y el porqué de la muerte de José Robles Pazos, para tender a un lado y a otro, paneles simétricos de investigación que de Estados Unidos a España, del padre a los hijos, hacen de todo un pasaje circular que subvierte en este punto concreto los códigos del cine negro. Con ánimo de ser más explicativos, nos hemos permitido dar un título acorde con su trama a cada uno de los siete apartados mudos que componen Enterrar a los muertos. El resultado es el siguiente esquema de vértices argumentales:

1. José Robles: estampa y relación con el investigador (De Estados Unidos a España)

2. Dos Passos, Hemingway y España (hasta 1937)

3. Dos Passos y la Guerra Civil (hacia la verdad)

4. ¿Quién y por qué asesinó a José Robles? [eje del relato]

5. Dos Passos sale de España: la huida (el terror tras la verdad)

6. Hemingway y Dos Passos: el después (recorrido circular) 
7. Los hijos de José Robles: continuidad y fuentes de la crónica (los intentos de regresar a Estados Unidos)

Como se puede comprobar, Martínez de Pisón rompe con audacia la sintaxis policiaca al mostrarnos todo lo que le ha sido posible averiguar sobre la muerte de Robles Pazos en el capítulo cuatro, esto es, en la mitad exacta del libro: es la cima. Más tarde, nos tocará descender su tragedia con los sucesivos periplos de sus conocidos: Dos Passos, Hemingway, Miggie y Coco. Desde esa atalaya, puede resultar extraño que, sin ningún dato investigador más por ofrecer, el ritmo de la narración siga sosteniéndose cuesta abajo, pero impera el eficaz ralentí del género. A fin de cuentas, como dijeran Alan Silver y Elizabeth Ward, el noir sirve ante todo como «pizarrón en el que América inscribe sus males para liberarse con este gesto catártico» (en Simsolo, 2009: 40). También España. Al cabo, «a Robles se le detuvo para ejecutarle y, por perverso que parezca, era su ejecución la que debía convertirse en la principal prueba de su traición. No se fusiló a un traidor: se fusiló a un hombre para hacer de él un traidor» (Martínez de Pisón, 2006: 110). Quede memoria.

Y quede iluminado, de paso, el cuarto de atrás de esta izquierda cainita que acapara las negruras de Enterrar a los muertos y Las serpientes ciegas, dos obras tan solitarias en sus formatos (a pesar de su reconocimiento) como perfectamente contrastables entre sí. Surgidas de un magma común, comunicables por la estética que rodea sus disparos, tan solo separadas por una brecha fantástica..., aunque esto sea como decir un abismo. Lástima que no haya más detectives que se atrevan a cruzarlo.

\section{BIBLIOGRAFÍA}

AlARY, Viviane (2011): «La novela gráfica en la historieta contemporánea», en Geneviève Champeau, Jean-François Cacelén, George Tyras y Fernando Valls (eds.), Nuevos derroteros de la narrativa española actual, Prensas Universitarias de Zaragoza, Zaragoza, pp. 217-234.

Altarriba, Antonio (2009): El arte de volar, Edicions de Ponent, Castalla.

BAREA, Arturo (2001): La forja de un rebelde. Vol. 3. La llama, pról. de Luis Antonio de Villena, Bibliotex, Barcelona.

BARTHES, Roland (1987): «El efecto de realidad», en Roland Barthes, El susurro del lenguaje. Más allá de la palabra y la escritura, Paidós, Barcelona, pp. 179-187.

BAyARrI, Frances (2009): Cita en Sarajevo, Ediciones Intervención Cultural, Vilassar de Dalt. 
Becerra Mayor, David (2015): La Guerra Civil como moda literaria, Clave Intelectual, Madrid.

BESSIÈRE, Irene (2001): «El relato fantástico: forma mixta de caso y adivinanza», en David Roas (ed.), Teorías de lo fantástico, Arco/Libros, Madrid, pp. 84-104.

CAILlois, Roger (1966) [1958]: Imágenes, imágenes... (sobre los poderes de la imaginación), Edhasa, Barcelona.

CAndeloro, Antonio (2016): «Luis Gasca y Román Gubern, El universo fantástico del cómic, Cátedra, Madrid, 2015, ISBN: 978-84-376-3439-5», en Brumal. Revista de investigación sobre lo fantástico / Brumal. Research Journal on the Fantastic, vol. IV, núm. 2, pp. 275-279. <https://doi.org/10.5565/rev/brumal.30>

Castex, Pierre-Georges (1951): Le conte fantastique en France, Librairie José Corti, París.

Castro, Antón (2005): «Entrevista con Ignacio Martínez de Pisón», en Antón Castro, disponible en <http:/ / antoncastro.blogia.com/2005/022801-entrevista-con-ignacio-martinez-de-pison.php $>$ [12/12/2016].

Cercas, Javier (2001): Soldados de Salamina, Tusquets, Barcelona.

Ceserani, Remo (1999): Lo fantástico, trad. de Juan Díaz de Atauri, Visor, Madrid.

Debord, Guy (2002): La sociedad del espectáculo, pról. y trad. de José Luis Pardo, Pre-textos, Madrid.

Dos Passos, John (1984): Años inolvidables, trad. de José Luis López Muñoz, Seix Barral, Barcelona.

García Lorca, Federico (2006): Poeta en Nueva York, (ed. de María Clementa Millán), Cátedra, Madrid.

GAsca, Luis y Román Gubern (2015): El universo fantástico del cómic, Cátedra, Madrid.

Giménez, Carlos (2011a): Paracuellos, Debolsillo, Barcelona. (2011b): Todo 36-39. Malos tiempos, Debolsillo, Barcelona.

FrANKLIN, Bruce H. (1979): «What are we to make of J.G. Ballard's Apocalypse?», en Thomas Clareson (ed.), Voices for the Future. Essays on Major Science Fiction Writers. Volume Two, Bowling Green University Popular Press, Ohio, pp. 82-105.

Hernández Cava, Felipe, y Bartolomé Seguí (2008): Las serpientes ciegas, Asociación Cultural BD Banda, Pontevedra. (2011): Hágase el caos, Norma, Barcelona.

JAMESON, Fredric (1999): «Las antinomias de la posmodernidad», en El giro cultural. Escritos seleccionados sobre el posmodernismo 1983-1998, Manantial, Buenos Aires, pp. $77-104$.

KRISTEVA, Julia (1978): Semiotiké, Fundamentos, Madrid.

LoAch, Ken (dir.) (1995): Land and Freedom (Tierra y libertad), Parallax Pictures, Reino Unido.

MARTínez de Pisón, Ignacio (2006): Enterrar a los muertos, Seix Barral, Barcelona.

MARTínez Rubio, José (2015): Las formas de la verdad: investigación, docuficción y memoria en la novela hispánica (2000-2015), Anthropos, Barcelona.

Molina GIL, Raúl (2015): «De lo subatómico a lo inmenso. Sobre la posible influencia de la Teoría de la Relatividad y la Mecánica Cuántica en lo fantástico», en Brumal. Revista de Investigación sobre lo Fantástico / Brumal. Research Journal on the Fantastic, vol. III, núm. 2, pp. 177-202, disponible en <http:/ / revistes.uab.cat/ 
brumal/article/view/v3-n2-molina [7/11/2016]. <https://doi.org/10.5565/ rev/brumal.148>

Muñoz Molina, Antonio (1986): Beatus Ille, Seix Barral, Barcelona.

MuÑoz Rengel, Juan Jacinto (2010): «La narrativa fantástica en el siglo xxI», en David Roas y Ana Casas (coords.), Lo fantástico en España (1980-2010), monográfico de Ínsula, núm. 765, pp. 6-10.

Orwell, George (2010): Orwell en España: Homenaje a Cataluña y otros escritos sobre la Guerra Civil española, ed. de Peter Davison, trad. de Antonio Prometeo Moya, Tusquets, Barcelona.

PARKer, Alan (dir.) (1987): Angel Heart (El corazón del ángel), TriStar, Estados Unidos.

Peris Blanes, Jaume (2011): «Hubo un tiempo no tan lejano... Relatos y estéticas de la memoria e ideología de la reconciliación en España», $452^{\circ} \mathrm{F}$. Revista electrónica de teoría de la literatura y literatura comparada, núm. 4, pp. 35-55, disponible en <http:/ / www.452f.com/index.php/es/jaume-peris-blanes.html> [7/11/2016].

Pizzolato, Nic (cr.) (2014): True Detective, Home Box Office, Estados Unidos, 20142015.

Pons, Álvaro (2009): «El cómic como análisis descreído», El País, 5 de noviembre, disponible en <http://cultura.elpais.com/cultura/2009/11/05/actualidad/125 7375603_850215.html> [7/11/2016].

RoAs, David (2001): «La amenaza de lo fantástico», en David Roas (ed.), Teorías de lo fantástico, Arco/Libros, Madrid, pp. 7-44.

(2011): Tras los límites de lo real. Una definición de lo fantástico, Páginas de Espuma, Madrid.

RodrígueZ, Alberto (dir.) (2014): La isla mínima, Atresmedia Cine, Atípica Films y Sacromonte Films, España.

Rom Rodríguez, Josep A. (2010): «Las viñetas de la fantasía. Cómic fantástico de autor en las últimas décadas», en David Roas y Ana Casas (coords.), Lo fantástico en España (1980-2010), número monográfico de Ínsula, núm. 765, pp. 6-10.

RosA, Isaac (1999): La malamemoria, Del oeste, Badajoz.

Rossif, Frédéric (dir.) (1963): Mourir à Madrid, Ancinex, Francia.

SÁnchez Noriega, José Luis (1998): Obras maestras del cine negro, Mensajero, Bilbao.

Simsolo, Noël (2009): El cine negro: pesadillas verdaderas y falsas, trad. de Alicia Martorell Linares, Alianza Editorial, Madrid.

Todorov, Tzvetan (2001): «Lo extraño y lo maravilloso», en David Roas (ed.), Teorías de lo fantástico, Arco/Libros, Madrid, pp. 65-82.

VAx, Louis (1960): Arte y literatura fantástica, Eudeba, Buenos Aires.

VÁzquez Montalbán, Manual (1990): Galíndez, Seix Barral, Barcelona.

ZıомeK, Henryk (1983): Lo grotesco en la literatura española de Siglo de Oro, Ediciones Alcalá, Madrid. 